The Version of Record of this manuscript has been published and is available in ANNALS OF LEISURE RESEARCH (2016) http://www.tandfonline.com DOI: $10.1080 / 11745398.2016 .1151368$

\title{
On Performing Art Jewellery: Identity play as leisure activity
}

\author{
Sian Hindle \\ Rachael Colley \\ Anne Boultwood
}




\begin{abstract}
Although the wearer is central to the understanding of jewellery of all kinds, the ways in which art jewellery is consumed as a leisure activity has received little critical attention. This paper seeks to situate the socially meaningful practices of art jewellery, with reference to social psychology (Markus and Kitayama 1999) and the sociology of Giddens (1991) and Goffman ([1959] 1990), as well as Butler's ([1990] 2006) concept of performativity, in order to explore how jewellery is used to articulate aspects of the self. The paper draws on a small scale primary research project, in which participants - new to this kind of adornment - wore, discussed and responded to both their own precious, traditional jewellery and a range of pieces of art jewellery.
\end{abstract}

Whereas discussion of the participants' own jewellery illustrates how it serves to lock them into place within their network of family and friends, their experiences of engaging with the art jewellery exemplifies their status as autonomous, bounded individuals. Trying on and responding to the art jewellery serves as a kind of identity play, extending the range of embodied practices available to the participants and allowing them to engage with non-normative performances of the self. This suggests that wearing art jewellery may serve as a form of performative leisure, disrupting the range of corporeal experiences open to women and creating the potential for change. The novelty of this approach stems from interrogating data derived from creative research methods using a conceptual framework that examines the mechanisms by which the self is constituted, establishing this as a new contribution to the fields of both leisure research and art jewellery.

Keywords: art jewellery; conventional jewellery; play; self; embodiment; performativity.

\title{
Introduction
}

Pressures to perform jewellery historically stem from ritual, ceremony and tradition. However, performative facets from within the broad spectrum of jewellery create distinctions and dichotomies that can be explored. The dichotomy between conventional, precious jewellery and what might, provisionally, be described as its flip-side - art jewellery - is of particular significance here, as the different ways in which they are selected, collected and performed as a leisure activity can reveal much about the way adornments are used to articulate identity itself.

The contexts in which jewellery is produced and consumed are under-theorised, and studies of the wearer's experience are more limited still. The role of pleasure has been touched on (Skinner 2013, Quickenden 2000), as has play and absurdity (Broadhead 2005, Astfalck 2005a). However, there is less work that 
attempts to theorise the degree to which the pleasure and fun associated with art jewellery operates in parallel with the criticality that challenges conventional mores and norms, and of how both are expressed through wear. Here, we consider some of the ways in which playful encounters with art jewellery are able to challenge hegemonic structures and facilitate the exploration of new forms of identity, a challenge that is able to account - at least in part - for the appeal of collecting and wearing art jewellery as a leisure activity.

The paper is the result of a study, entitled 'Strange Pleasures', in which the creative research method of annotated silhouette drawing was trialled and its potential explored. A wealth of data was generated in the course of the project, including the participants' drawings, photographs that the participants directed, and film footage and still images taken by the researchers. During analysis, a number of key themes emerged around the role of adornments in articulating aspects of the self, and the significance of ambivalence in the wearing of jewellery. This paper focuses on the differences in the performances that are generated through the wearing of conventional-precious jewellery and art jewellery, and explores the versions of the self that are articulated through their use. Considering how the adornments impact on the embodied identity of the participants allows us to explore jewellery's potential in enabling participants to engage with aspects of 'corporeal style' (Butler [1990] 2006, 190) that are, perhaps, experienced as marginal to everyday life. Indeed, identity play can be seen as central to the experiences that are documented by the participants and this is explored in relation to Butler's ([1990] 2006) concept of performativity. Leisure studies' concern with the dimensions of leisure, measured in terms of action on the one hand and structure on the other (Haywood 1995), raises questions around freedom and control that are pertinent to the experience of wearing a range of adornments. Adjacent fields - fashion theory, psychology of the self, sociology - are also drawn upon in order to deepen and develop our understanding of the jewellery field.

\section{Literature review}

\section{Jewellery and its contexts}

Traditional, precious jewellery crystalizes links between people and across generations. Its generally small size means that it can be worn or carried next to the body (Hughes 1966), and it becomes a private, intimate carrier of meanings and memories that often only the wearer will be able to retrace (Habermas 2011). And yet, there is a public face to traditional, precious jewellery; it marks the 'spectacle of the everyday' (den Besten 2011,12), serving public functions of marking status, relationships, remembrance, etc, using symbols and shorthand with which we are familiar in the West (and increasingly in the East), such as the diamond-set engagement ring worn on the left hand.

Compared with these well known symbols, art jewellery is very different. Known variously as art jewellery, contemporary jewellery or as The New Jewellery (although this latter term is now somewhat dated, and has fallen from 
use), Skinner (2013) describes its production as a self-reflexive practice that relates to the body. Den Besten (2011) also highlights the self-reflexive nature of the field, and both highlight the arc of production and use:

[Art] jewellery [is] observed and researched as a phenomenon, envisioned as a work of art, created as a piece of jewellery and perceived as a controversial piece that needs a spirited wearer but finds its utmost power of expression when combined with the full knowledge of the concept, material and history. (den Besten 2011, 15)

Since its inception in the 1960s, art jewellery has been challenging the definitions of jewellery that seek to identify it as being merely a 'pretty adornment for the wealthy' (ACJ 2004, 10), used to shore up identity in entirely conventional ways (Dormer and Turner 1994).

A range of critics have explored the drive by jewellers and wearers of jewellery to make adornment more than merely incidental and supplementary (Adamson 2007, Derrez 2005, Phillips 1996). However, this frequently leads to it becoming regarded as an art form - in effect, as mini-sculpture (Dormer and Turner 1994, Drutt, English and Dormer 1995, Sandino 2002) - and this contributes to the rather troubled relationship that art jewellery has with the body. Although Skinner (2013) comments on how the exhibition plinth serves as an abstracted body, the sequestering of art jewellery in a showcase or within the gallery space tends to put the jewellery beyond use, with the result that it is cut off from criticism, challenge and engagement with the bodies that activate it through use (Staal 2005, den Besten 2014).

This is, of course, to simplify considerably. Plenty of artists and jewellers have sought to explore the possibilities for wear, asking how the interactions with the body can add layers of meaning to the jewellery. This involves fruitfully working across boundaries with interactive art forms such as performance art, installation, video, interactive art and photography (Broadhead 2005, Lignel 2006, den Besten 2011, Astfalck 2005b). Performance as means of demonstration has long been associated with craft (Cassel Oliver 2010), but more recently performance has been used to question craft's position in the art and design canon, with some examples drawing the audience into the process as participants (Craig 2012, Lanchester Gallery 2015) and breaking into the private realm that jewellery often occupies (Skinner 2013).

Skinner (2013) explores the range of contexts - page, bench, plinth, drawer, street, body, world - in which art jewellery is produced and consumed, the list serving to highlight the sometimes blurred distinctions between maker and wearer, collector and viewer. Art jewellery is not a separate and self contained leisure activity: individuals may be involved as makers, collectors and wearers, making the boundary between, for example, leisure and work indistinct. Nevertheless, attempts to redefine art jewellery as an artistic discipline, with specialist galleries, collectors and patrons, mean that - despite its democratic ideals - the contexts in which it is usually found are almost inevitably elitist. Indeed, the nomenclature of 'art jewellery' itself has been criticised for valorising 
artistic merit, at the expense of other aspects, such as use of technology and multiple production techniques (Unger 2012). Beyond the makers who are involved in the field, art jewellery as an artistic discipline is generally available only to a clientele who are wealthy enough to afford its purchase or who have the education or experience to seek out the exhibitions and publications in which it can be found. While its exclusivity may well represent part of the appeal for this group, the sense of elitism that surrounds it constrains its accessibility as a more mainstream leisure activity made up of consumption and wear.

While the reflexive quality of art jewellery is foregrounded by many (Skinner 2013, den Besten 2011), the criticality of work within the field has sometimes been overlooked. One of the key features of much art jewellery is the way that it engages critically with its social, environmental, political, or creative context; Melland's powerful piece, '687 Years' is made of used intrauterine devices (IUDs), bringing an artefact that has been worn within the body out into view and raising important questions about the nature of women's reproductive control (Holmen 2013). This gives rise to the possibility of art jewellery being used to articulate resistance to the hegemonic power structures; Astfalck (2005b) foregrounds art jewellery's fruitful occupation of the space between more mainstream discourses and the dialogue that this promotes.

Another aspect that has perhaps been overlooked is the pleasure that can be provided through engagement with jewellery. When worn, the placement of the jewellery next to the skin can increase the wearer's awareness of parts of their body that usually go unnoticed (Quickenden 2000); when seen on others, it can lead to a vicarious identification with the wearer (Broadhead 2005). Conversely, feelings of anxiety may also accompany the wearing of jewellery that stand out so sharply against the context in which they are worn. The tension between pleasure and anxiety helps to locate the collection and wearing of art jewellery as a leisure activity, and to define its potential: there is immense fun to be had in wearing adornments that mark the wearer out as unique, playful and confident, but there is also a learning process through which the experience of being noticed itself is negotiated and managed (Stebbins 1992, Calley Jones and Mair 2014). Adorning the body with art jewellery and exposing this to a public audience itself generates debate, perhaps all the more so because the big ideas raised by some pieces of art jewellery contrast so sharply with the very personal, individual meanings and memories that are associated with traditional, precious jewellery.

\section{Adorning the body; performing the self}

The relationship between the body and the psyche is complex, with each working upon the other through a range of mechanisms. The body serves as a selfing device (Baerveldt and Veostermans 1998), allowing the individual to both engage with the ongoing experience of self as well as creating an identity or outward expression of self. In this way it represents an interface between the world and the individual. Much has been written about the ambiguous way in which clothes are used to mark this boundary, by - for example - simultaneously 
concealing and revealing the body (Bancroft 2011, Boultwood and Jerrard 2000, Entwistle 2000, Harvey 2007). Of course, jewellery is not (usually) functional in the practical sense of keeping one warm and covered, but it does serve a signifying role, communicating meaning (around a constellation of ideas concerning status, religious belief, degrees of conformity, etc) through its use and wear; and this is an important distinction. While the selection, wearing and interpretation of clothing is influenced - at least in part - by something beyond conscious control (Boultwood and Jerrard 2000), jewellery tends to be scrutinised at a more conscious level by the wearer, simply because of the primacy of meaning (den Besten 2011). Within the field of jewellery, thoroughgoing theoretical explorations of this aspect are limited. There are a number of studies around the wearing of jewellery (Habermas 2011, Cheung 2006, Ramljak 1997, Cunningham 2007), although there is a tendency to focus discussion on the degree to which wear activates the jewellery (Ramljak 1997, Skinner 2013, Cheung 2006), rather than on how, conversely, jewellery - in facilitating this selfing process - activates the wearer. Hence, jewellery is able to foreground aspects of the wearer's identity, both for the observer, who might experience the pieces visually, and for the wearer, who may draw on a broader range of senses, including the haptic senses. The degree to which wearers are able to manipulate these signifiers, in order to keep these aspects of identity circulating, is of key interest to the study of jewellery as a leisure activity.

Scholarship about the body is necessarily tempered, because of the different perspectives that are at play. Just as the limits of the physical body are contested, with increasing awareness of the porous nature of body/skin (Blackman and Rose 2013), so the psychological limits of the self are disputed (Rozin et al. 1995, Anzieu and Turner 1989). Whereas self-awareness grounds us in the body, the ability to 'decentre' and imagine the perspectives of others provides us with an external perspective, and together these form the hypothetical construct of the body boundary. Here, the terminology of the body draws the physical into play in articulating the psychological limits of the self, which is grounded in awareness of the body but tempered by the social and cultural messages that are reflected back at us (Boultwood and Jerrard 2000).

The need to establish a convincing and consistent narrative of the self that spans these two perspectives, that both the individual and the surrounding social group can have confidence in, is highlighted by Goffman ([1959] 1990) and Giddens (1991). These two sociologists consider how our everyday routines help to maintain the fiction of an abiding self. Goffman ([1959] 1990) uses the term dramaturgy to describe the process by which we inhabit a range of social roles, as if engaged in a stage performance. While Goffman ([1959] 1990) makes the point that increasingly proficient performances lead both performer and audience to believe wholeheartedly in the drama that unfolds, for Giddens (1991), the need for this fiction highlights the precariousness of our sense of ontological security. In the face of this, weaving the various events of our lives to create a narrative that stresses persistence and continuity requires a degree of reflexivity, which allows us to constantly monitor our performance and gauge our own and others' reactions, and to change course if appropriate. It is through the process of reflecting and responding that one takes control of the process of 
constituting the embodied self that is presented - at least in the West - to the world, balancing opportunity and risk in order to forge a unique identity and a coherent narrative. Butler ([1990] 2006) describes how this monitoring becomes internalised and non-conscious: the repetition and ritualization of embodied behaviours leads to a limiting of possibilities - a 'corporeal style' (Butler [1990] 2006, 190), of which gender is one aspect - that the body as cultural sign can adopt. Hence, 'bodily gestures, movements, and styles of various kinds' (Butler [1990] 2006, 34) create the illusion of an abiding self that is, in reality, nothing more than the performance itself, the playing out of the corporeal style. Some time has passed since all three theorists - Giddens, Goffman and Butler - first presented their thinking around the constitution of self and identity; however, limited theorisation within the study of art jewellery means that there are still valuable insights to be gained from applying their ideas to the ways in which body ornamentation is worn and experienced.

From the perspective of fashion theory, Boultwood (2003) has described how the better the fit between body and clothes (in both a physical/psychological sense), the less conscious the performance is. In the case of art jewellery, the goal is not so much to 'fit' as to highlight difference and the resulting performance can be a highly mannered one, a point that Sandino (2002) makes (albeit in gendered terms). Art jewellery can be notoriously difficult to wear, such is its size, position on the body or its subject matter (Dormer and Turner 1994). It sometimes seeks to challenge the equilibrium of the self by destabilising body boundary, shifting self-awareness by constricting or extending body parts (Bonansinga 2008) or by provoking the viewer (Skinner 2013). Because of these factors, art jewellery has the potential to put the corporeal style through which the self is performed under tension: familiar gestures or movements seem unnatural, and - taken to extremes - the self is brought up short against its own constructed, performative nature.

Engaging in this performance is a challenge and there are limited numbers of people wishing to take it on; the coterie of people prepared to wear art jewellery is therefore small, a point that both Noten (Staal 2005) and den Besten (2014) make in their manifestos. Of course, when wear becomes too problematic, photography is frequently used to document performances that are too uncomfortable or challenging to be sustained in public (den Besten 2011). Short of this point, the performance must be reflexively monitored and adjusted by the wearer to ensure that, through the use of effective impression management (Goffman [1959] 1990), a compelling and believable front is presented. Observation of this ongoing reflexive process could best be carried out with a sample made up of those with little direct experience of wearing art jewellery, and the decision was made to recruit participants for the research on which this paper is based from outside the coterie referred to above.

\section{Methodology}

The 'Strange Pleasures' project sought to explore the way in which a small group of women responded to the experience of wearing (rather than creating, viewing 
or owning) art jewellery. Using a community setting in an ethnically diverse area of south west Birmingham, UK, and contacts at a community group, an opportunity sample of 4 women was recruited for a small, intensive study that took place in May 2014. The women were aged between 32 and 42 and were known to each other through the playgroup their children attended: two identified their ethnicity as white British, one as English/Welsh and one as Asian. The nature of the study was discussed with the participants, with participants being informed of its focus on the wearing of jewellery and the feelings this provoked. Prior to the session, each participant was asked to bring a piece of jewellery that they wore on a regular basis and that they were happy to discuss with the group. They were informed that discussion of this would be followed by an opportunity to try on and discuss pieces of 'art' or 'contemporary' jewellery, defined loosely as jewellery made from unusual materials, worn in unexpected ways or with the intention of expressing a range of ideas or concepts. While pseudonyms have been used for this analysis, the participants' anonymity is inevitably somewhat compromised by the use of photography; this was discussed with the participants and their informed consent documented.

The key questions that provided the focus for this study centred around the participants' embodied experiences of wearing art jewellery. Additional, related questions included the issue of whether the participants' embodied experiences differed when they wore different types of jewellery, and whether this impacted on the performance of self. This small scale trial sits within a broader research project exploring the embodied experiences of wearing art jewellery, allowing the piloting of methods before they are rolled out in the full study. This broader project is practice-led, with data being gathered and analysed through interviews and a reflective and iterative drawing process. This pilot study provided an opportunity to explore possibilities of engaging participants creatively with the research process by asking them to produce images of their own.

After an initial introduction, where a discussion took place around the research, its aims and methods, and informed consent was sought and documented, the first half of the session was spent in discussing the jewellery that the participants wore regularly. Each person was invited to share the story of the piece they had brought with them, possibly touching on how it came into their possession, when they wore it and how it made them feel. After this, the women were provided with electronic tablets and asked to work either individually or in pairs to take a photograph of themselves that reflected the way the piece of jewellery made them feel. There was then further discussion of the images within the group. 


\section{(a)}

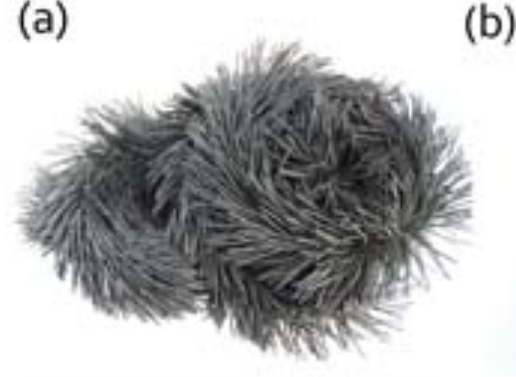

(b)

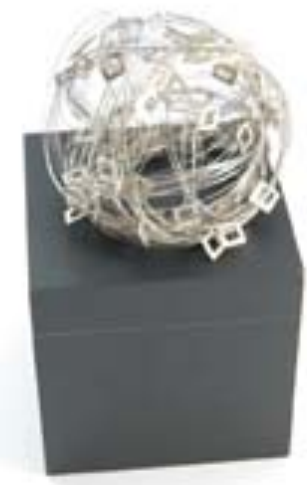

(d)

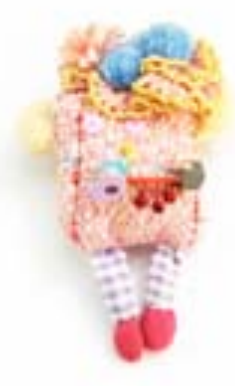

(g)
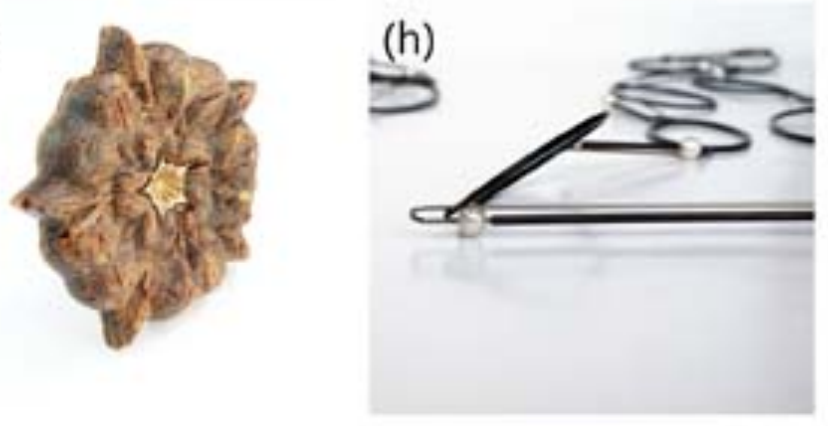

(e)
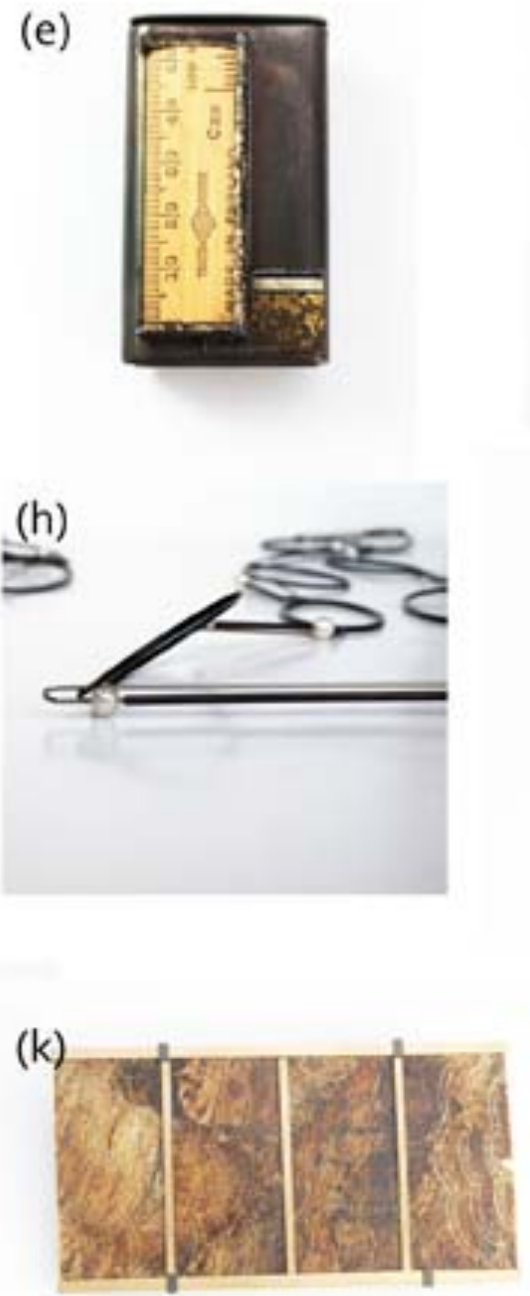

(f)

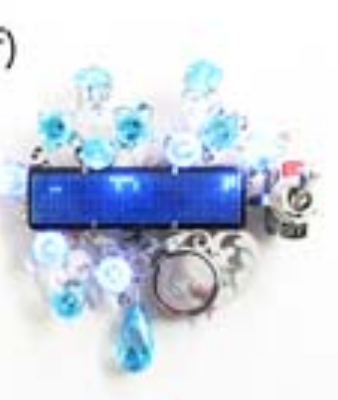

(i)

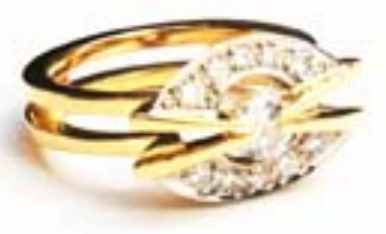

(l)
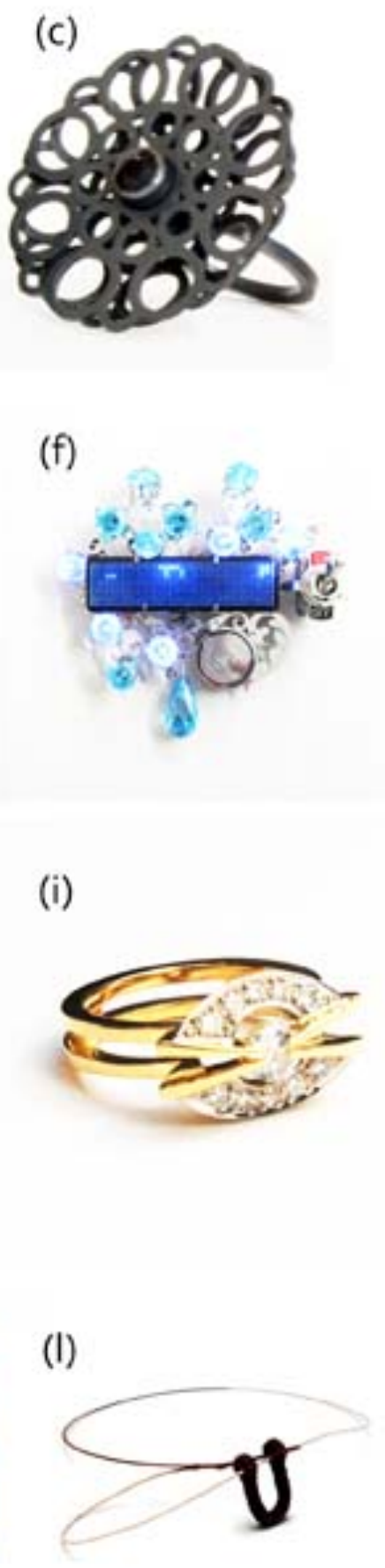

Fig 1. Pieces of art jewellery:

(a) Zoe Robertson, 'The Diva Boa' (boa: neoprene rubber and stainless steel wire)

(b) Anna Lorenz, 'Ware and Wear' (sculptural piece and neckware: stainless steel, silver and display box)

(c) Toni Mayner, 'Donning Oxford' (ring: oxidised silver and sapphire)

(d) Sally Collins, 'Say Whaaaaaaaat?!' (brooch: cotton, fabric, varnished base metal and sterling silver)

(e) Jo Pond, 'Helix Rule' (brooch: recycled Oxford set of mathematical instruments) 
(f) Lisa Juen, 'Don't dream it, wear it' (brooch: stainless steel, cubic zirconia and electrical components)

(g) Rachael Colley, 'Doggy Dodger' (brooch: British beef, gold plated silver and stainless steel)

(h) Toni Mayner, 'Chain reaction' (chain: oxidised silver, stainless steel and freshwater pearls)

(i) Gaynor Andrews/Peter Slusarzcuk 'Ring' (ring: diamond and 18ct gold)

(j) Shona Marsh, 'Contemporary Art Deco Ring' (ring: green tourmaline, diamonds and 18ct gold)

(k) Rachael Colley, 'Wafers' (brooch: British beef, gold plated brass, oxidized silver, rubber, flour, egg and stainless steel)

(l) Toni Mayner, 'Lost and found' (neckpiece: U-bolt with threadbound stainless steel microcable)

In the second half of the session, the participants were invited to handle and try on a variety of pieces of art jewellery that had been loaned by colleagues at the School of Jewellery, Birmingham City University. These are shown in Fig. 1. The jewellery was laid out on large sheets of white paper and the details of maker, type and materials were provided (see Fig. 2); two of the pieces were made of beef and, knowing that some people may not be comfortable handling meat, they were alerted to this. Once participants had selected a piece of jewellery that they wanted to wear, they were asked to stand next to a large piece of paper onto which was projected a silhouetted image of themselves. This shadow was then traced in pencil by the researchers, thus providing a silhouette outline that participants could then annotate with a range of media to depict how it felt to wear the jewellery. Lastly, the participants were asked to direct the lead researcher taking a photograph of themselves with the piece of jewellery. 


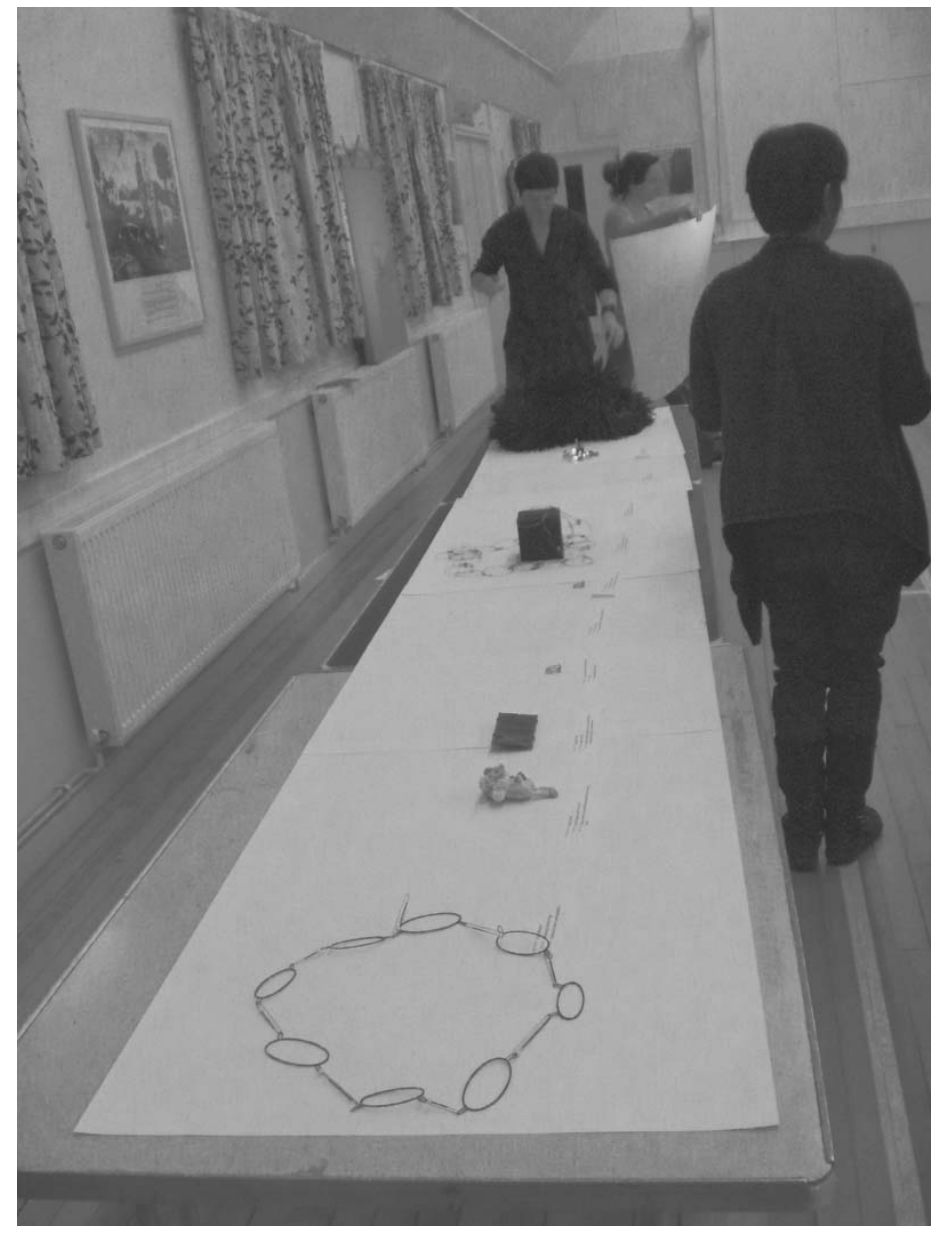

Fig 2. Range of art jewellery pieces displayed on white paper, with labels.

The whole session was video recorded, and the visual information produced was analysed, along with the transcript, using NVivo software.

\section{Findings}

The images produced during the session are shown in Fig. 3. 
(b) Annotated

(a) Participants silhouette drawings, wearing art jewellery wearing art jewellery
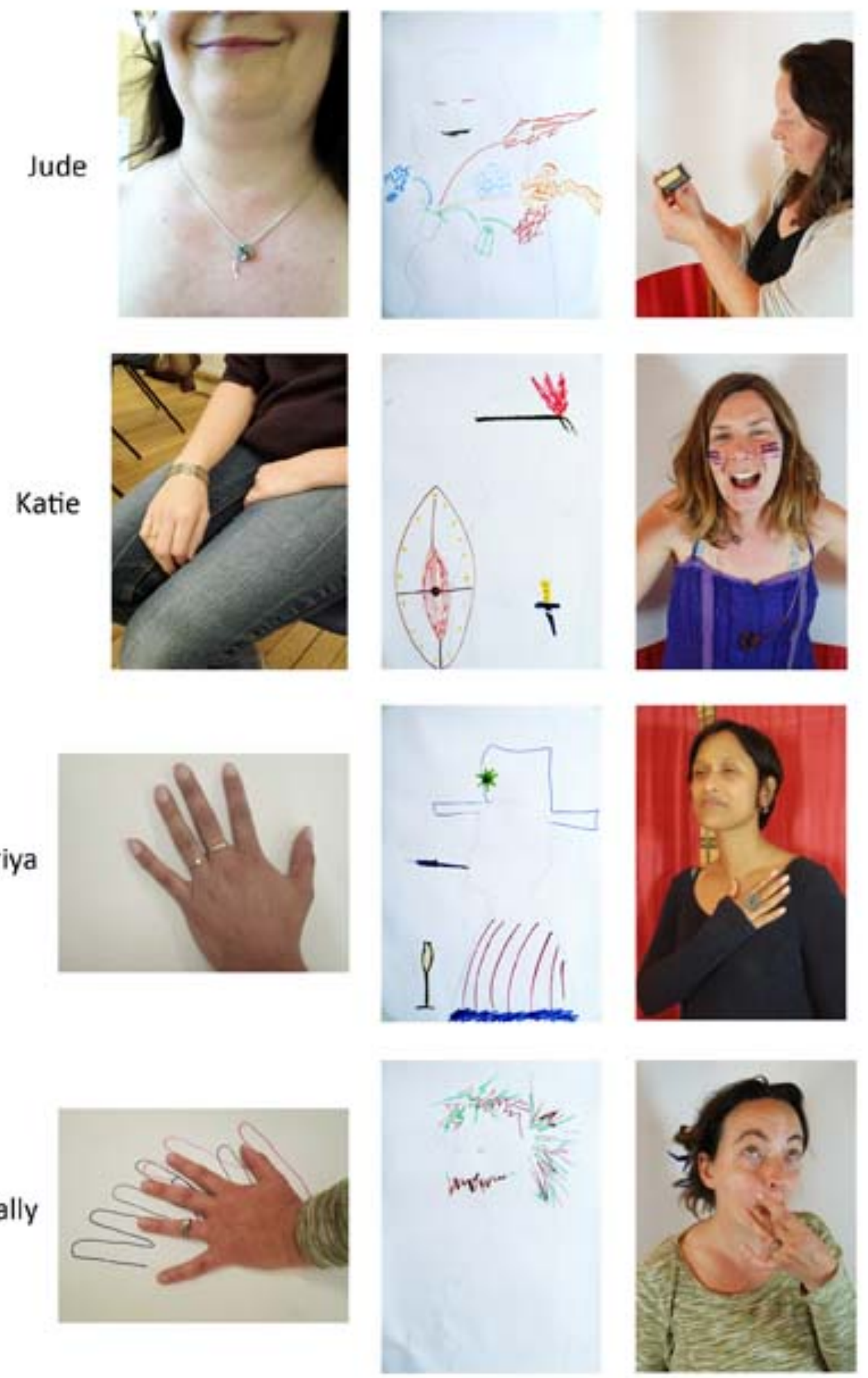
Fig. 3. Images produced/directed by the participants during the session.

The participants brought a range of their own jewellery pieces with them to the session. Jude referred to her silver wedding ring, but focused principally on a silver, fuchsia flower pendant that had been made for her by a friend who is a jeweller. No clothing was included in the photograph that she took of herself wearing the pendant, reflecting, she said, the fact that 'it just makes me feel naknaked without it' (Jude). Katie brought a bracelet and ring that were given to her by a family friend who had taken her own life; she wanted to show herself happy and at ease - 'I might just sit there with a cheesy grin' (Katie) - and her photograph shows her sitting with her jewelled hands in her lap. Priya brought her diamond engagement ring, and took a simple image of the ring on her finger; she reported that her fondness for the ring was tinged with sadness, as she was currently unable to locate her wedding ring. Sally also brought her engagement ring, and referred to her platinum wedding ring. The engagement ring had been worn, previously, by women from earlier generations of her family and Sally acknowledged these women by drawing around her hand in coloured pens and photographing her hand, wearing the ring, on top. As she says: 'that's all the ladies that have had the ring' (Sally).

All of the pieces discussed were gifted to the participants, from friends (both living and deceased), family and a partner. Initially, the discussion centred around the intrinsic, material value of the jewellery, and pieces made from noble metals, such as gold and platinum, were considered to be 'proper' (Katie) whereas others, such as those made in silver, occupied a more marginal position: for instance, Jude spoke of 'my lovely wedding ring, which my husband had the cheek to barter down from 4 quid to 3 pound' (Jude). As the discussion developed, however, talk centred on the more complex meanings and memories that the pieces had acquired through their histories. Several of the pieces had had more than one owner, and there was considerable talk about the lineage of the pieces and the impact this had on the experience of wearing the jewellery. Most of the participants arrived wearing the pieces that they discussed to the session. Katie's bracelet and ring, on the other hand, were wrapped up in paper and carried in a bag; of them, she said: 'Don't wear mine! Mine sit in the box!' (Katie).

When the participants were invited to try on and respond to the art jewellery, there was excitement at having the opportunity to handle a range of unusual jewellery pieces. Engaging through touch became compelling, and touching with the fingers alone was not enough: participants were soon expressing an interest in exploring the tactile qualities of the pieces in other ways: 'I just want to put my face in it' (Sally, of Robertson's 'Diva Boa') and 'I don't know why, but I really want to lick this! I just want to know what it is!' (Jude, of Colley's 'Wafers' brooch). Jude had to be cautious about the materials she had physical contact with as she has an allergy to the zinc that is present in many metal alloys. Nevertheless, the broad range of materials used was clearly intriguing for the participants, and Colley's use of (dried) beef, in particular, triggered a range of responses, from confusion ('I thought it was made from wood' [Katie]) and 
surprise ('Is it really?! Really?' [Jude]) to more nuanced feelings ('it was almost like that weird attraction/revulsion thing' [Sally]).

Asked to choose a piece that they felt drawn to and would like to wear, Jude selected the 'Helix Rule' brooch (Fig. 1[e]), as the thought that the lidded vessel could contain anything appealed to her: 'I think I just like the tin, because it was so...open to suggestion' (Jude). Her drawing reflects this, as it shows ideas, imaginary creatures and memories flooding out of the space within, and the photograph she directs shows her peering into the open tin vessel. Katie selected the 'Lost and Found' neckpiece (Fig. 1[1]), saying that it reminded her of a piece of jewellery given to her by her partner. She said that it made her feel 'tribal' (Katie), and her silhouette drawing is annotated with a feather headdress, shield and a weapon in the form of a knife. Taking this idea further, she was photographed with felt-tip 'war paint' (Katie) on her face, filling the image with her arms outstretched. Priya selected the 'Donning Oxford' ring (Fig.1[c]), saying, 'it was probably the sort of thing I would wear' (Priya). Priya described the ring as 'a very elegant piece' (Priya), adding accessories to her silhouette in the form of clothing, jewellery, a champagne glass and a cigarette in a holder. The photograph that she directed shows her staring into the distance, with her ringed hand held up to her chest. Sally selected the 'Doggy Dodger' brooch (Fig. 1 [g]), identifying a visceral feeling that she had in response to the beef the piece was made from: 'but it's a real - how do I describe it? - it comes from here [indicating her chest]' (Sally). She acknowledged that she found other pieces more visually appealing, but what she described as 'that weird attraction/revulsion thing' (Sally) made this piece stand out from the others. Sally felt that the strange appeal of this material was at odds with her stated vegetarianism, and her drawing shows jagged, zigzagging lines in contrasting colours around the lips and mouth of her silhouette. The brooch does not feature in the photograph she directed, but instead she holds her fingers up, as if she has just delivered food to her mouth. As she said, 'It was a very odd thing. I just responded to it, in that I smelled it, and wanted to bite it' (Sally).

\section{Discussion}

\section{Participants' own jewellery}

There was little about the jewellery that the participants brought with them to the session that would place it beyond the range of what one might expect for jewellery worn routinely, in terms of size, type and material, and in terms of the connotations associated with the items: a pendant reminded the wearer of a friend; a bracelet was kept in memory of a deceased friend; gem set engagement rings were used to indicate commitment. Semiotically, these pieces function indexically/metonymically, in that they point to something bigger than themselves, rather like carrying a bit of the person around with them. There are parallels with Winnicott's transitional object (Winnicott 1992), in that they allow the wearer to maintain a relationship with the absent party, but they also open up a personal space in which the wearer can be herself. The tangible nature of these objects is significant, as - unlike the people they are associated with - they 
are stable and controllable (Habermas 2011), and hence they serve to reinforce trust and the social bonds between family and friends.

Here, Habermas' (2011) insights are borne out by the hypothetical construct of the body boundary, an ambiguous boundary that is derived from both the selfawareness that is rooted in one's own body and the sense of oneself that is reflected back from others and from society at large (Boultwood and Jerrard 2000). While the degree of definition that individuals experience differs, it is likely that jewellery that is worn regularly (a wedding/engagement ring, for instance) becomes absorbed within the body boundary, and hence becomes part of both the self that the wearer feels herself to be and the self she sees reflected back at her by others. Most of the pieces the participants brought (with the exception of Katie's bracelet/ring) are worn on a daily basis. Jude talked about feeling naked without her pendant: given that she reported wearing it for long periods of time, both day and night, this suggests that it may have been absorbed - through wear - into her body boundary and become important to her self identity. The construct of the body boundary provides a means of understanding how jewellery that metonymically refers to another can end up being absorbed into the self.

The nexus of interconnections spoken of by participants as they discussed their own jewellery highlights the interdependency of close family and friends in a way that is perhaps more familiar within collectivist, Eastern cultures, such as Japan and China (Markus and Kitayama 1999). Within such cultures, a relational view of self predominates: rather than the individual being primarily responsible for articulating the unique qualities of the self (the independence model of the West), the self is construed through relationships with others (Markus and Kitayama 1999). Within this study, relationships are clearly important to the participant's understanding of their jewellery. The stories associated with the pieces are contingent and oriented towards others: Sally draws the hands of the women who have worn the ring as if their fingers still share the space with hers; unwrapping her jewellery, Katie remembers the family friend who helped her with maths when she was at school. These are shared objects, and wearing them (and, to a lesser extent, keeping them) could be understood as an acknowledgement of the part other stakeholders play in the wearer's identity.

The routines associated with jewellery - giving it, wearing it, bequeathing it, sharing it out after a death - provide us with what Giddens describes as ontological security (Giddens 1991), feeling that one's experience is ordered, that it makes sense and that it will continue to do so. The wearing of wedding/engagement rings and the handing on of jewellery between generations featured strongly in discussion, and with good reason: both practices stress continuity through time. Routines such as these allow us to handle dangers or threats according to emotional and behavioural formulae (Giddens 1991), providing a useful shorthand that allows us to maintain 'normal appearances' (Goffman 1971, 238). Routines like these allow us to go on in the face of crippling anxiety or angst, and help to explain the popularity of Mah Rana's Meanings and Attachments project, which was initiated in 2002 and now takes the form of a tumblr page (Rana n.d.) to which the public are invited to 
contribute; it comprises more than 1500 photographs and written accounts of what jewellery means to its wearers.

Investing - financially, but also emotionally - in the material value of jewellery is another routine. The material value of the jewellery was commented on by most participants when the jewellery was first shown to the group. When they talked about the materials used, they were attempting to agree on whether or not it would reach the benchmark of being valuable in the most universal, economic terms. There seem to be mixed feelings about value, and Jude reported pressure to trade in her cheap silver ring for a platinum one; she was reluctant, saying, '[a]t the end of the day, I love the ring' (Jude). For her, there was clearly a tension between the relatively low material value of the silver ring and the precious feelings the ring symbolizes. Nevertheless, the reference to material value in many of these early discussions points to the pervasiveness of this particular routine. The security it provides extends into the future, so long as we have trust in the monetary system. Indeed, for Katie, her jewellery provides very real reassurance in hard times, as she says, 'when I [...] had no money, I thought I could always pawn that ring upstairs' (Katie). In this way, routines help to highlight and indeed shore up identity across space and time, and provide a sense of stability.

Overall, then, the participants' own jewellery is associated with interdependence within networks of family and close friends, experienced at a fundamental level which ensures stability, continuity and security. Seen through the lens of the conventional jewellery, the participants' world of friendships, kin, self, body is highly structured. If this experience of being locked in place by the social roles one plays feels old fashioned, this is because jewellery has a long pedigree in this vein. Phillips (1996) describes how, in the medieval period, rings were used to seal (and hence authenticate) documents and secure betrothals, coronets were used to indicate married status and gold collars were used to indicate allegiance to a particular household. Jewellery's capacity to indicate status, allegiance, connections - one's place within the structure - has changed little since premodern times.

However, there is a danger that what is experienced initially as stability can eventually become constricting. Butler ([1990] 2006), highlighting the regulatory frame that patriarchy provides, describes how repeated embodied acts 'congeal over time to produce the appearance of substance' (Butler [1990] 2006,45 ); hence regulatory pressures, embodied and enacted through habitual performances, become apparently inescapable. Katie's comments about her inherited jewellery demonstrate the ambivalence she feels about jewellery's potential to sustain and congeal embodied practices across generations. Her experience of wearing the pieces is a frustrated one: the ring was too big for her and the bracelet was held together with a homemade repair. She was caught in a bind, unable to wear the pieces and yet unable to relinquish them either; the indebtedness of the gift (Mauss 1980) seemed to be tempering her enjoyment of the pieces, and she was left with jewellery that was, to some degree, burdensome. Conversely, Sally describes the 'really practical' (Sally) approach of her mother and aunts, who insisted on selling anything of value that they found 
at her grandmother's house after her death. Here, the exchange value of the pieces is foregrounded; redeeming the jewellery for cash means that the repeated, embodied practices associated with wearing (or keeping) the jewellery are refused and the intergenerational chain of repeated performances is broken.

\section{Art jewellery}

In comparison to the small, conventional and materially-valuable jewellery belonging to the participants, the art jewellery the participants in the study selected is extraordinary. Jude's selection was made from tin, with the signs of making still visible in the solder seams; Katie's featured a U-bolt, corroded with rust. Priya's choice was the most conventional, resembling - as it does - a cocktail ring, but Sally's was probably the most challenging, given that it was made from beef that had been dried and hardened, and formed into the design of a Tudor rose. More conventional pieces were available (more restrained gem set rings, for instance), but it is notable that, aside from by Priya, these were rejected in favour of more unusual adornments. Given the sharp contrast with the participants' own jewellery and their very limited knowledge of art jewellery, it is perhaps surprising that the response to these pieces was so positive.

There was a real sense of play within the group during this half of the session. The participants embraced the opportunity to try on the jewellery and treated it almost as children would play at dressing up: trying on items of jewellery, but also playing with the range of different identities that might accompany them. Hence, Katie plays with what she calls the 'tribal' (Katie) associations that are suggested by the neckpiece she wears, and Priya experiments with what Giddens (1991) describes as the sign equipment of the social class just above hers to articulate the elegance she feels. There is lots of laughter and noise within the room, and interaction between the participants is interspersed with moments of intense concentration. Just as dressing up is a finite activity for children, the participants are aware of the temporary, provisional nature of this interaction and do not (generally) want to take pieces home.

Play is a key element of art jewellery. Where conventional jewellery is often metonymic, art jewellery is frequently iconic, relying on visual cues to play with expectations and undermine one's sense of what is known. Both Broadhead (2005) and Astfalck (2005a) consider how many adornments draw on the slippery, arbitrary nature of visual signs in order to invoke humour, play and sometimes absurdity. In Colley's brooch, selected by Sally, beef is given the appearance of wood, creating a visual pun that charges a historical motif with new meanings and associations.

Part of this sense of play rests in the way that the adornments are able to challenge the routines that allow us, on the one hand, to go on but which risk, on the other, constricting our choices. Much art jewellery questions the notion of preciousness and value, through its use of a broad range of non-precious materials, but also through its embrace of the ephemeral and impermanent. Jewellery that changes over time disturbs because we expect our adornments to 
be stable and constant (Habermas 2011); jewellery that degrades or wears away is profoundly transgressive (Skinner 2013, Colley 2015). Moreover, the challenge that art jewellery offers extends beyond the materials used and the exchange value these carry; art jewellery deals with a broad range of issues including - to list just a few - ideals of beauty, the post-human body and reproductive health (see work by Kalman [2013], Zellweger [2007] and Melland [Holmen 2013]). Of course, the finite nature of this session means that this was a safe space in which the participants could engage in this process; knowing that they would leave these strange adornments behind meant they could play with impunity. And it could be argued that jewellery itself, because it is regarded as supplementary, as merely decorative, is also contained, making the playful exploration of challenging ideas safe (Voigt and Voigt 2011); we will return to this idea at the end of the article.

There is also some evidence that wearing the jewellery can challenge the participants' sense of embodied identity. Having selected Colley's beef brooch, Sally clearly felt a sense of dissonance: as a vegetarian she rejects meat, and yet she found that she wanted to ingest/consume the brooch. However, she also seemed to quite enjoy this feeling. It was a source of humour, and there was laughter from her and the others when she said 'But I'm a vegetarian!' (Sally). She held the audience's attention and seemed to enjoy performing with the piece; at the end of the session she admitted that it allowed her to easily complete the creative tasks of drawing and directing the photograph. It is part of the sense of play of the session that she doesn't have to resolve these dissonant feelings. Indeed, the other participants engaged in discussion that probes this focus on physical, material flesh. Memories were evoked of being reduced to their bodies, with Sally talking of 'everything that used to upset me about school photos' (Sally) and Jude recalling photos taken during pregnancy that show her to 'just look incredibly fat' (Jude). Discussion of animal flesh (the beef brooch and, later, black pudding) alongside their own flesh (during adolescence and pregnancy) foregrounds the commonalities between them, and this is highlighted by Sally's observation about the tactile experience of touching the beef: 'once I'd picked it up, I sort of regretted it slightly cos it was a bit sticky! (---) I became aware of that, actually, the more I held it, the warmer I made it, the stickier it got!' (Sally). While it is clearly Sally's bodily warmth that renders the beef sticky, it is also possible to imagine that the brooch itself is coming to life, further contributing to the impression that hierarchies are failing and order is slipping. The photo Sally directed shows her with a mouthful of food and no sign of the brooch, the implication being that she has eaten it. Alert to the transgressive nature of materials, Sally engaged with another transgression of her own in playfully imagining an end to the story that results in her eating the piece.

Of course, the art jewellery explored during the session had none of the grounding and potentially burdensome ties of the participants' own jewellery. The pieces facilitate the trying on of a temporary identity, to be played with during the session, and they do not have a history that needs to be accommodated by the wearer. If interdependence is an element of the participants' own jewellery, then we can see elements, here, of the independent 
construal of self that Markus and Kitayama (1999) associate with Western societies: the individual is regarded as self-contained and clearly-bounded, with a unique configuration of internal attributes. This focus on the individual, rather than their social and familial networks, leads to a plurality of choice - 'What to do, how to act, who to be?' (Giddens 1991, 70) - but also of risk. Whereas the stability glimpsed in discussion of the participants' own jewellery threatened suffocating normalcy, the opposite is true here and there is a danger of meaninglessness. Holding this threat at bay involves the participants in the creative process of actively constructing their own meanings, and this ushers in the identity play that is such a distinctive feature of the participants' engagement with art jewellery.

Even within a playful environment such as this, the need to create a convincing performance with a sustainable narrative crept upon them. The participants, after all, were using their bodies as a canvas for ornamentation and - if they were to maintain the notion, prized in the West (but illusory, according to Butler [[1990] 2006]) of the autonomous, abiding self - continuity must be preserved and a degree of consistency must be evident. Giddens (1991) highlights how the careful management of appearance and demeanour allows participants to move between different contexts and settings without threatening feelings of continuity across time and space. Here Sally's ability to stick to what Giddens (1991) describes as a bodily regime - the systems of bodily control (diet, dress, behaviour) that constitute this management - is called into question by the visceral response she reports to the beef brooch, and the (playful) suggestion that she lacks control and has eaten the brooch. This provoked a discussion of other bodily regimes amongst the group, that served as a counterpoint to Sally's challenge.

Three of the four women comment that they are or have been vegetarian or vegan, but their discussion of black pudding dances across both sides of the line of prohibition: Jude (who has been vegetarian, but now eats meat) said it was, 'alright, actually' (Jude) and Katie (who is currently vegetarian) said enthusiastically, 'it's lovely!' (Katie). The talk shifted to the lack of control of the body in adolescence (Sally described her discomfort at being captured in a school photograph 'covered in spots with my teeth [fingers splayed to indicate teeth protruding at various angles] like I used to have' [Sally]) and the lack of bodily control during pregnancy (Jude discussed the unfamiliar changes to body shape and size as the baby grew inside her).

The tensions described by the participants, here, are just those kinds of contradictions that Butler ([1990] 2006) argues subjects must struggle with, albeit largely unconsciously, as they attempt to forge an identity. It is interesting that three of the women recalled and shared moments at which their own corporeal style was either deliberately abandoned or found wanting, suggesting a degree of empathy with Sally. This disruption (real or remembered) to the 'act' of being an embodied human being (Butler [1990] 2006, 190) means that the fiction of the 'doer' as a being that exists prior to the act (Butler [1990] 2006, 34) is challenged, and the performance of the self is impacted as a result. What emerges is a series of creative acts in which the women work together to support 
Sally as she constructs an embodied performance that provides, on the one hand, sufficient disruption to fuel her need for a sense of agency and, on the other, the continuity that reassures those present that this really is Sally who is speaking to them. It seems that, for the participants, some of the appeal of the 'Strange Pleasures' workshop may stem from the creative process of exposing oneself to challenge and working, together, in a holistic, embodied way to find a solution.

Here, however, Sally suggested something a little different: in asking why the photographer should be so insensitive to the insecurities of teenagers, she suggested that the context - rather than the individual - should be changed. It could be argued that the play that marked the session throughout opened up a space in which the women are given permission to be conscious of their bodies, but also to acknowledge that sometimes bodily control is beyond them. It may be that the provisional nature of the identities that they have been trying on and experimenting with has given them the confidence to engage with those aspects of their embodied selves that they would usually only indulge in private.

\section{Conclusion}

Butler ([1990] 2006, 1993) repeatedly questions that which is defined as natural - sex, gender - by asking whether it is possible that these concepts are, instead, created by the patriarchal symbolic order for its own ends. She argues that 'performativity [can be] construed as that power of discourse to produce effects through reiteration' (Butler 1993, 20), and - in turn - shows how these effects are cast as foundational. We have seen how the embedded conventions of traditional, precious jewellery, with their conventional notions of value and validation of particular, sanctioned relationships, result in a performance of identity that is, largely, static, with limited affordances for playfulness. Butler ([1990] 2006, 1993) accepts that there is no escape from the power of discourse: to exist beyond the symbolic order is to find oneself beyond meaning. However, it is clear that play manages to undercut the logic of discourse. The diminutive and inconsequential light in which jewellery is itself regarded by many means that the behaviour it facilitates is often regarded as inherently playful (Voigt and Voigt 2011, Skinner 2013). Here, the jewellery enables the participants to engage in playful behaviour that is non-serious, bounded in both time and space and constrained by its own rules. In doing so, it demarcates a space in which the participants can reflect, safely and at some distance, on their own experiences. Play, as a result, opens up new possibilities; exploiting these possibilities, the women are able to turn discourse upon itself and use jewellery to 'forg[e] a future from resources inevitably impure' (Butler 1993, 241). The impurity offers promise because it hints at qualities that are both unsanctioned and disturbingly hybrid.

Here, we can see leisure in its two modalities: the women's own traditional, precious jewellery is primarily experienced in terms of a social system that structures and controls their behaviour into socially prescribed actions that draw on a constrained corporeal style; in contrast, the art jewellery that they explored during the study points to how the wearing of adornments can 
constitute a leisure experience that is one of freedom and play. Of course, the different faces of adornment that we have provisionally denoted as opposites for the purposes of this study - 'traditional' and 'art' jewellery - are rarely entirely discrete entities, and we must accept that, beyond the heightened contrasts we have presented here (traditional, regularly worn jewellery and newly encountered art jewellery) shades of grey can be found. Adornments can combine big ideas and precious materials, and - through gifting and wear conceptually challenging pieces can also point to relationships with loved ones. Nevertheless, setting them against each other in this fashion has allowed us to explore how play allows the wearer to create a sense of space within social structures. The performance of drag that Butler describes in Bodies that Matter (Butler 1993) results in a repetition of gender roles in a way that foregrounds their constructed nature; hence drag becomes a parody of a parody (Butler 1993). This study points to how jewellery as performative leisure manages, in the same way, to facilitate and enable disruption by repeating normative behaviours while at the same time pulling and stretching them to incorporate new meanings and interpretations, challenging the sometimes limited range of women's experiences and creating genuine potential for personal change.

\section{Acknowledgments}

The authors would like to thank the women who generously gave their time for the 'Strange Pleasures' study, our colleagues at the School of Jewellery for the loan of their adornments, and Toni Mayner for her support and assistance.

\section{References}

ACJ 2004. Jewellery Unlimited, London, ACJ.

ADAMSON, G. 2007. Thinking Through Craft, Oxford, Berg.

ANZIEU, D. \& TURNER, C. 1989. The skin ego, London, Yale University Press.

ASTFALCK, J. 2005a. Difference and Resemblance: The reconstruction of signs. In: JONSONN, L. (ed.) Craft in Dialogue: Six views on a practice in change. Stockholm: IASPIS.

ASTFALCK, J. 2005b. Jewellery as a Fine Art Practice. In: GRANT, C. (ed.) New Directions in Jewellery. London: Black Dog Publishing Ltd.

BAERVELDT, C. \& VEOSTERMANS, P. 1998. The Body as a Selfing Device: The Case of Anorexia Nervosa. In: HENDERIKUS, J. S. (ed.) The Body and Psychology. London: Sage.

BANCROFT, A. 2011. Inspiring Desire: Lacan, Couture, and the Avant-garde. Fashion Theory, 15, 67-82.

BLACKMAN, L. \& ROSE, N. 2013. Crossing Neuroscience and the Humanities [Online]. London: Centre of the Body, Goldsmiths, University of London. Available: http://www.gold.ac.uk/podcasts/.

BONANSINGA, K. 2008. Equilibrium: body as site. Metalsmith, 28, 6-6-42.

BOULTWOOD, A. 2003. Fashioning the Body: An investigation into the relationship between fashion and the body. Doctor of Philosophy, University of Central England. 
BOULTWOOD, A. \& JERRARD, R. 2000. Ambivalence, and Its relations to fashion and the body. Fashion Theory, 4, 301-321.

BROADHEAD, C. 2005. A Part/Apart. In: GRANT, C. (ed.) New Directions in Jewellery. London: Black Dog Publishing Ltd.

BUTLER, J. [1990] 2006. Gender Trouble: Feminism and the subversion of identity, Abingdon, Routlegde Classics.

BUTLER, J. 1993. Bodies that Matter: On the discursive limits of 'sex', London, Routledge.

CALLEY JONES, C. \& MAIR, H. 2014. Magical Activism: What happens between the worlds changes the worlds. Annals of Leisure Research, 17, 296-313.

CASSEL OLIVER, V. 2010. Craft Out Of Action. Handmade: The performative impulse in art and craft. Houston, Texas, USA: Contemporary Arts Museum Houston.

CHEUNG, L. 2006. Wear, Wearing, Worn: The transition of jewels to jewelry. In: SACKVILLE, A. (ed.) New Directions in Jewellery II. London: Black Dog Publishing Ltd.

COLLEY, R. 2015. Spurious Luxus. Zètēsis, 2, 96-103.

CRAIG, G. 2012. The Pro Bono Jeweler [Online]. Available: http://www.gabrielcraigmetalsmith.com/index.php/projects/the-probono-jeweler/ [Accessed 23 February 2015].

CUNNINGHAM, J. 2007. Contemporary European Narrative Jewellery. Doctor of Philosophy, University of Glasgow.

DEN BESTEN, L. 2011. On Jewellery: A compendium of international contemporary art jewellery, Stuttgart, Arnoldsche.

DEN BESTEN, L. 2014. The Golden Standard of Schmuckashau [Online]. California, USA: Art Jewelry Forum. Available:

http://www.artjewelryforum.org/articles/the-golden-standard-ofschmuckashau [Accessed 18 February 2015].

DERREZ, P. 2005. Jewellery? What kind of jewellery are we actually talking about? In: GRANT, C. (ed.) New Directions in Jewellery. London: Black Dog Publishing Ltd.

DORMER, P. \& TURNER, R. 1994. The New Jewelry: Trends and traditions, London, Thames and Hudson Ltd.

DRUTT ENGLISH, H. W. \& DORMER, P. 1995. Jewelry of Our Time: Art, ornament and obsession, London, Thames and Hudson Ltd.

ENTWISTLE, J. 2000. Fashion and the fleshy body: dress as embodied practice. Fashion Theory, 4, 323-323-347.

GIDDENS, A. 1991. Modernity and Self-Identity: Self and society in the late modern age, Cambridge, Polity Press.

GOFFMAN, E. 1971. Relations in Public: Microstudies of the public order, London, Allen Lane The Penguin Press.

GOFFMAN, E. [1959] 1990. The Presentation of the Self in Everyday Life, London, Penguin Books.

HABERMAS, T. 2011. 'Diamonds are a Girl's Best Friend': The psychology of jewellery as beloved objects. In: LINDEMANN, W. (ed.) Thinking Jewellery: On the way towards a theory of jewellery. Stuttgart: Arnoldsche Art Publishers.

HARVEY, J. 2007. Showing and Hiding: Equivocation in the relations of body and dress. Fashion Theory, 11, 65-94. 
HAYWOOD, L. 1995. Understanding leisure, 2nd ed. Cheltenham: Stanley Thornes. HOLMEN, M. 2013. The Uniqueness of the Masses [Online]. Oslo, Norway: Norwegian Crafts. Available: http://www.norwegiancrafts.no/magazine/01-2013/the-uniqueness-ofthe-masses [Accessed 9 January 2014].

HUGHES, G. 1966. Jewelry, London, Studio Vista Ltd.

KALMAN, L. 2013. Portfolio [Online]. Available: http://laurenkalman.com/art/Portfolio.html [Accessed 25 March 2013].

LANCHESTER GALLERY 2015. FlockOMania, Coventry, Lanchester Gallery.

LIGNEL, B. 2006. On Defining Contemporary Jewelry. Metalsmtih, 25, 14-15.

MARKUS, H. R. \& KITAYAMA, S. 1999. Culture and Self: Implications for cognition, emotion and motivation. In: BAUMEISTER, R. F. (ed.) The Self in Social Psychology.

MAUSS, M. 1980. The Gift, London, Routledge and Kegan Paul.

PHILLIPS, C. 1996. Jewelry: From antiquity to the present, London, Thames and Hudson Ltd.

QUICKENDEN, K. 2000. Pleasure and Pain. In: QUICKENDEN, K. (ed.) Virtual Gallery of Contemporary Jewellery. Birmingham: University of Central England.

RAMLJAK, S. 1997. Keeping Vigil: Jewelry, touch and physical engagement. American Craft, 38-41.

RANA, M. n.d. Meanings and Attachments [Online]. Available: http://meaningsandattachments.tumblr.com [Accessed 27 July 2015 2015].

ROZIN, P., NEMEROFF, C., HOROWITZ, M., GORDON, B. \& VOET, W. 1995. The Borders of the Self: Contamination sensitivity and potency of the mouth, other apertures and body parts. Journal of Research in Personality, 29, 318-340.

SANDINO, L. 2002. Studio Jewellery: Mapping the Absent Body. In: GREENHALGH, P. (ed.) The Persistence of Craft. London: A\&C Black.

SKINNER, D. (ed.) 2013. Contemporary Jewelry in Perspective, New York: Lark Jewelry and Beading.

STAAL, G. 2005. Ted Noten: CH2, Rotterdam, 010 Publishers.

STEBBINS, R. A. 1992. Amateurs, Professionals and Serious Leisure, Montreal, Canada, McGill-Queen's University Press.

UNGER, M. 2012. Freedom has its limitations: Jewellery today, seen from a Dutch perspective [Online]. Munich: Premsela, Netherlands Institute for Design and Fashion. Available: http://www.die-neue-sammlung.de/blog/wpcontent/uploads/2012/03/Marjan-A21.pdf [Accessed 27 July 2015].

VOIGT, S. \& VOIGT, U. 2011. Head Jewellery - A theory of the theory of jewellery. In: LINDEMANN, W. (ed.) Thinking Jewellery: On the way towards a theory of jewellery. Stuttgart: Arnoldsche Art Publishers.

WINNICOTT, D. W. 1992. Playing and Reality, London, Routledge.

ZELLWEGER, C., MARGETTS, M. \& GASPAR, M. 2007. Foreign bodies: Christoph Zellweger, Barcelona, Actar. 